\title{
Oceanographic and meteorological effects on autumn sea-ice distribution in the western Arctic
}

\author{
ROBIN D. MUENCH \\ Science Applications International Corporation, 13400B Northup Way, Suite 36, Bellevue, WA 98005, U.S.A. \\ Carol H. Pease and Sigrid A. Salo \\ Pacific Marine Environmental Laboratory, NOAA, 7600 Sand Point Way NE, Seattle, WA 98115, U.S.A.
}

\begin{abstract}
Oceanographic, meteorological and sea-ice data were obtained from the northern Bering Sea and Chukchi Sea during the autumns of 1987 and 1988. Iceedge location was observed from ships and via AVHRR satellite data, and ice-drift information was obtained from ARGOS-tracked drift buoys. Meteorological data were obtained from ships, from an ARGOS-tracked meteorological station and from synoptic charts. The ice edge was significantly farther south in 1988 than during other years and impacted the Alaskan coastline. In 1987, the ice edge was, conversely, anomalously far north. Ice melt-back in certain regions, such as along the Alaskan coast and in Herald Canyon, was due to input from warm ocean currents. The largerscale interannual differences in ice extent were, however, due to interannual differences in the regional winds. In particular, the anomalous and extreme southward extent of the ice edge during 1988 was due to northerly to northwesterly winds, which held the summer pack ice against the the beach. Meltwater from this ice salt-stratified the upper water column, so that the ice eventually became effectively insulated against vertical flux of heat from the underlying warm water in the coastal current.
\end{abstract}

\section{INTRODUCTION}

The FREEZE experiment was designed to determine the regional ice budget and mechanisms for air-ice-ocean interaction in the eastern Chukchi Sea (a peripheral sea of the Arctic Ocean), and the northeastern Bering Sea, as ice begins to form in the autumn. The study area extended from St. Lawrence Island in the south to the Chukchi Sea ice edge in the north (Fig. 1). The eastern boundary was the Alaskan coast and the western limit was the international border with the Soviet Union, which runs from Anadyr Strait to Bering Strait and continues northward along $169^{\circ} \mathrm{W}$. The area comprises two extensive shelves, separated by Bering Strait. Depths are generally less than $50 \mathrm{~m}$ except along the northern Chukchi Sea shelf break (the $100 \mathrm{~m}$ isobath bordering the Arctic Ocean), in the Hope Sea Valley, and southwest of Anadyr Strait in the Bering Sea (Fig. 1).

The field work reported here consisted of three cruises aboard the NOAA ship Surveyor. The first two cruises occurred on 17 August to 16 September and 10 to 22 October 1987, and an additional cruise was conducted on 20 September to 14 October 1988. Three ARGOS-tracked drifting-ice buoys and one ARGOS meteorological station were deployed in the northeastern Chukchi Sea, from the Surveyor, during September 1987 and were serviced during October 1988. These units measured atmospheric sea-level

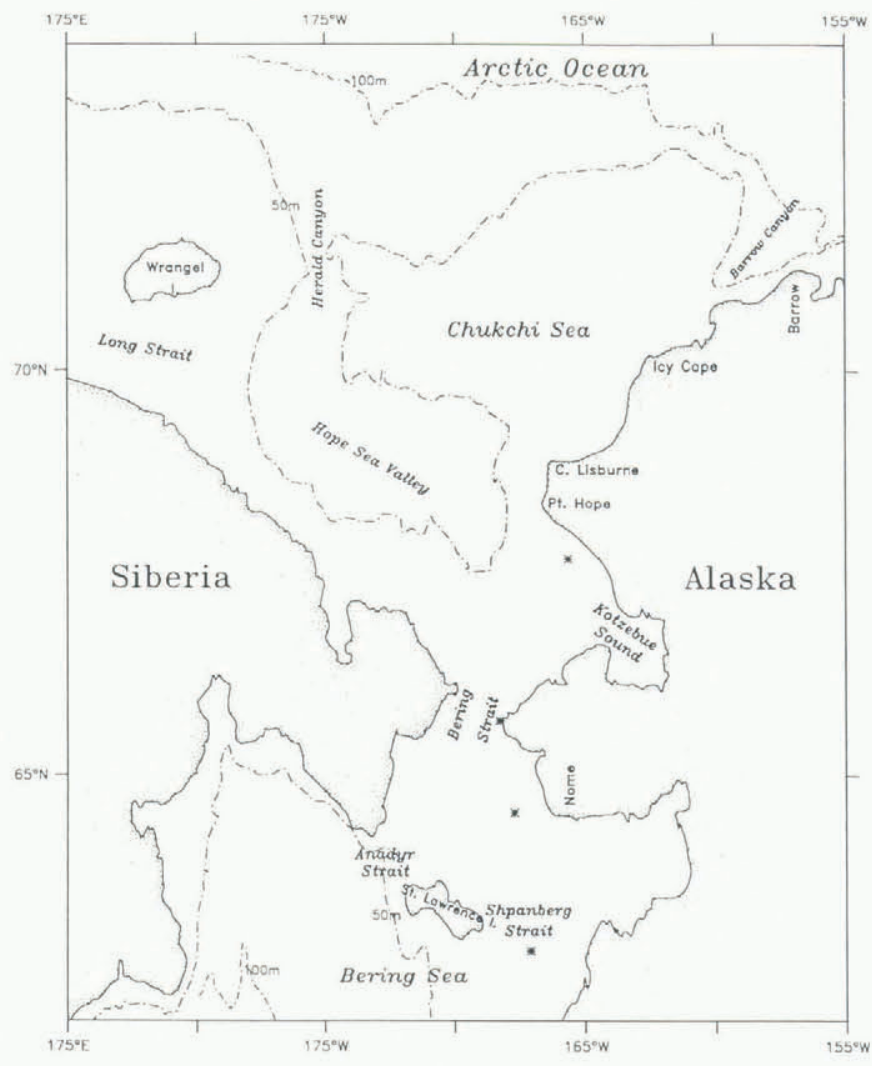

Fig. 1. Location map for the FREEZE study region. 
Muench and others: Sea-ice distribution in western Arctic


Fig. 2. Sea-level air temperatures and computed wind velocities for fuly-October 1987 and 1988: (a) at $66^{\circ} \mathcal{N}-$ $169^{\circ} \mathrm{W}$ in the northern Bering Sea-Bering Strait region and (b) at $72^{\circ} \mathrm{N}-150^{\circ} \mathrm{W}$ in the northern Chukchi Sea region. 
pressure and ventilated air temperature. The meteorological station also measured winds at $2 \mathrm{~m}$ elevation and currents $6 \mathrm{~m}$ below the ice. The lifetime of these units varied from 4 months to 2.5 years. However, the meteorological station broadcast for only 15 days in 1987 and 3 months in 1988. All data were retrieved via NOAA polar-orbiting satellites through Service ARGOS of Toulouse, France.

Additional meteorological data were obtained from aboard ship and from synoptic sea-level pressure charts. Wind fields were interpolated between known points by computing gradient winds from sea-level pressures. Sea-ice distributions were obtained from aboard ship and from NOAA AVHRR (Advanced Very High Resolution Radiometer) visible and infrared satellite imagery.

This paper focuses on the sea-ice distribution, compares the observed 1987 and 1988 distributions with the interannual mean, and briefly discusses this comparison vis-á-vis the regional meteorological and oceanographic conditions.

\section{METEOROLOGICAL CONDITIONS}

Temperatures, wind speeds and directions during the July-October summer-winter transition periods for 1987 and 1988 are shown for the northern Bering Sea and northern Chukchi Sea regions (Fig. 2). Winds were relatively weak and variable in direction during July to early August of both 1987 and 1988. The highest winds for both years occurred during roughly month-long episodes of northerly winds following the onset of autumn storm activity (Overland, 1981; Overland and Pease, 1982; Pease, 1987). In the northern Bering Sea, winds in 1987 were mostly northerly from 1 September to early October whereas, in 1988, sustained northerly winds persisted from mid-August to late September (Fig. 2a). These northerly winds were more pronounced in Bering Strait and the northern Bering Sea (wind speeds of $25 \mathrm{~m} \mathrm{~s}^{-1}$ ) than in the northern Chukchi Sea (speeds of $10 \mathrm{~m} \mathrm{~s}^{-1}$ ) (Fig. 2b). In fact, persistent northerly winds did not occur over the Chukchi Sea except for 14d episodes in September 1987 and August 1988. A prolonged wind event, with speeds of order $10 \mathrm{~m} \mathrm{~s}^{-1}$ from the west-southwest, lasted two weeks in late September and early October 1988 to northwest of Barrow (Fig. 2b). These anomalous winds were caused by a $980 \mathrm{mbar}$ low-pressure system centered $500 \mathrm{~km}$ northnorthwest of Barrow (outside the region shown on Fig. 1).

Air temperatures were highly variable in both years, reaching maxima in July and August, then tapering off through radiative cooling as fall progressed (Maykut and Church, 1973; Pease, 1987) (Fig. 2). In general, 1988 was warmer than 1987, especially in September.

\section{OCEANIC CONDITIONS}

Regional oceanographic conditions in the study area are dominated by the northward flow of Pacific Water, which has been conditioned by cooling and freshening (depending upon the season) during its transit over the Bering Sea shelf, through Bering Strait and across the Chukchi shelf. This water provides heat which can delay early winter ice formation.
Data obtained during the Surveyer cruises determined the oceanic temperature and salinity fields at the onset of the winter freeze and revealed interannual variations in these fields (Salo and others, 1990). In August 1987, oceanic isotherms and isohalines paralleled the Chukchi Sea coastline and nearshore temperatures were as high as $6-7^{\circ} \mathrm{C}$ throughout the water column. This warm band, which extended north of Barrow, was separated from offshore waters by a nearly vertical front. The warm nearcoastal water and associated front reflect a warm, coastally trapped current which is normally present through summer and autumn (Wiseman and Rouse, 1980; Ahlnäs and Garrison, 1984).

Surface salinities were minimum nearshore (about 30 ppt) in August 1987, except off Icy Cape where values decreased offshore to minima (27-28 ppt) associated with the melting ice edge. These salinity minima were confined to the upper ocean, leading to a strong salinity-controlled vertical density stratification. The condition was highly seasonal, since by October the nearshore waters had cooled to less than $2{ }^{\circ} \mathrm{C}$, salinity had increased, and isotherms and isohalines had become nearly perpendicular to the coastline.

Water transport through Bering Strait is typically greater in July and August than at other times of the year (Aagaard and others, 1985; Coachman and Aagaard, 1988). Therefore, one might expect an enhanced supply of Bering Sea water to the southern Chukchi Sea during those months and to the northern Chukchi Sea by AugustSeptember. However, water temperature at Shpanberg

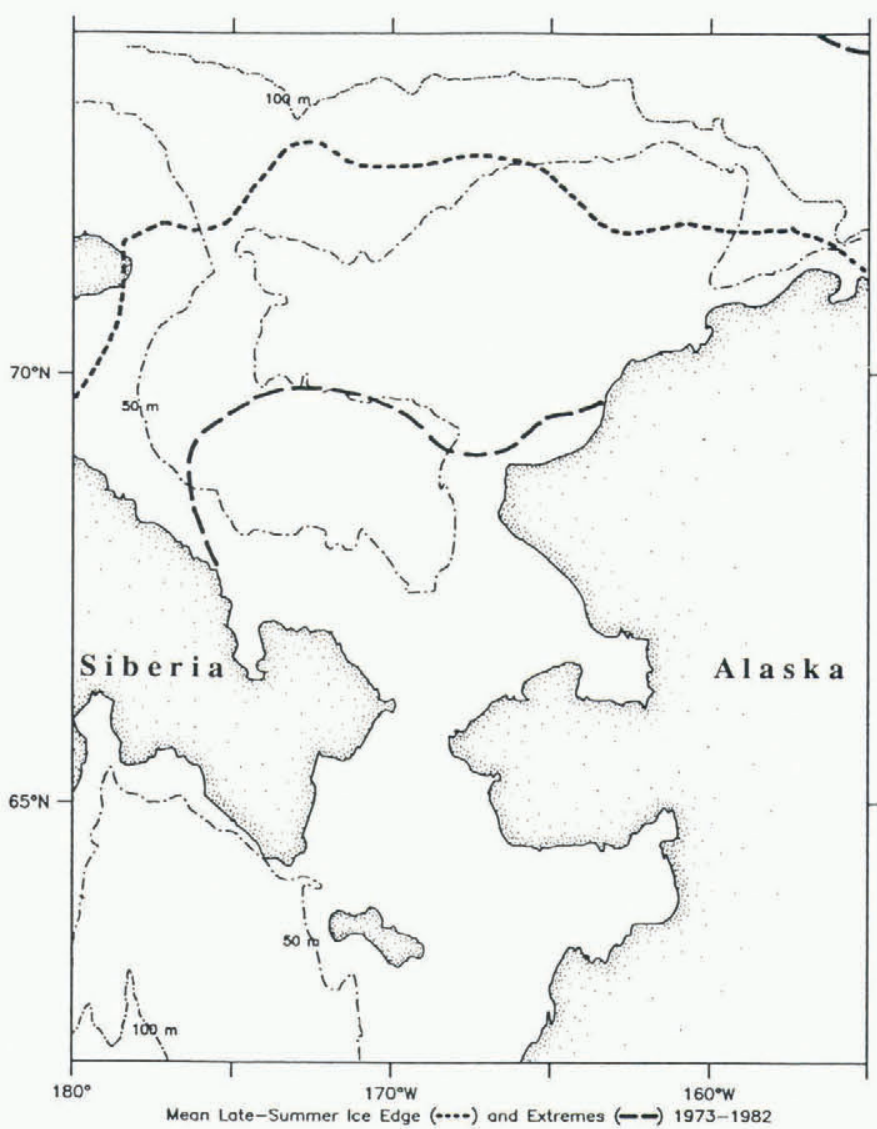

Fig. 3. Mean ice-edge location in the western Arctic for the period 1973-82. Extreme northward extent is outside the area covered by the figure. 
Strait and Cape Rodney increased steadily over the period when transport was presumably decreasing, at least in 1987, during August-October. The effects of the two seasonally varying parameters, transport and water temperature, partially cancelled each other out.

Interannual variations were observed throughout the region but were greatest in the northern Chukchi Sea.
There, surface oceanic isotherms and isohalines were nearly $2^{\circ}$ farther north in 1987 and 1989 than in 1988, coincident with the northward displacement of the ice edge during those years. However, the sub-surface water at $20 \mathrm{~m}$ and $35 \mathrm{~m}$ depth in the same region was actually cooler in 1987 and 1989 than during 1988.
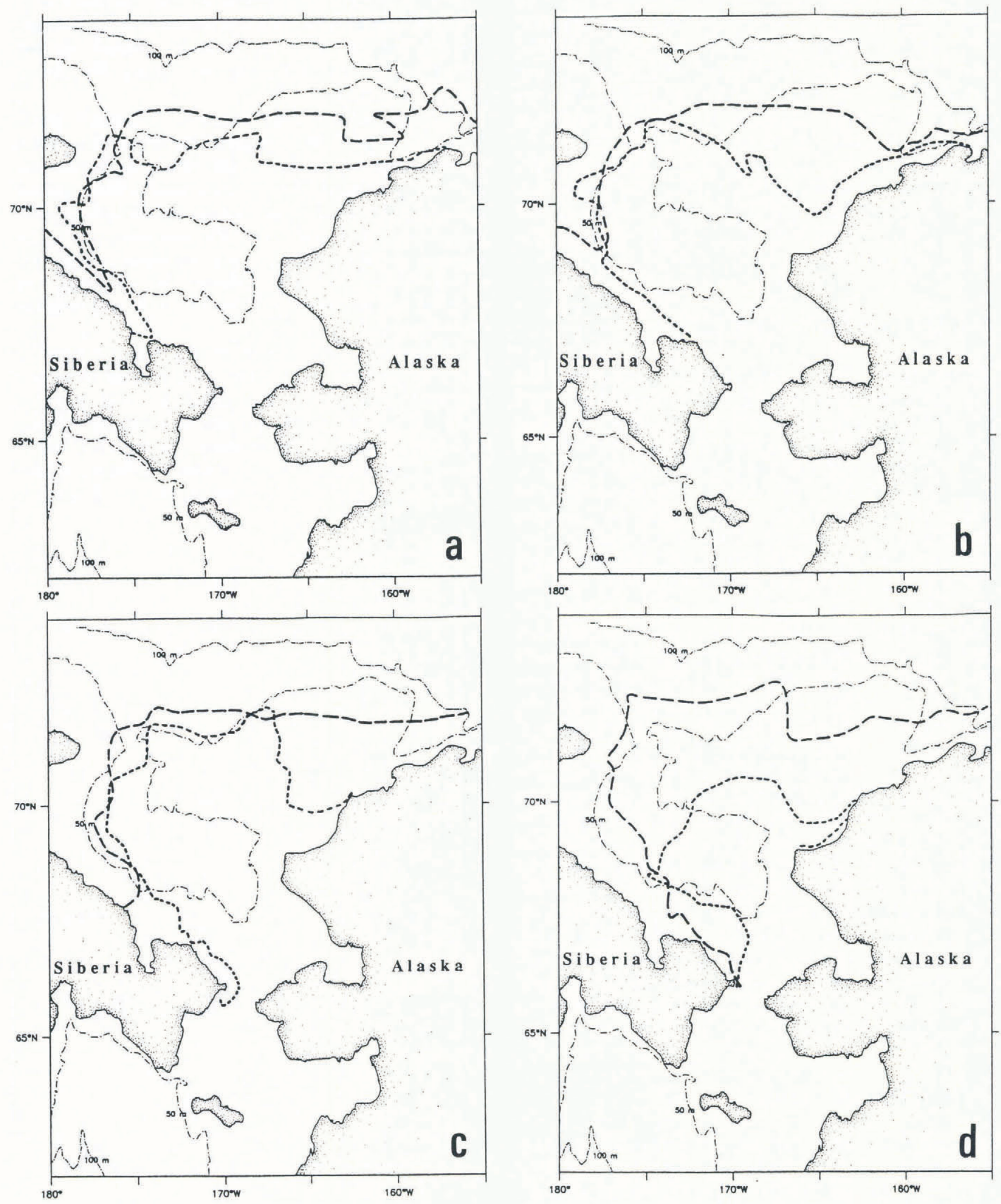

Fig. 4. Observed ice-edge locations on: (a) 1 September 1987 and 30 August 1988, (b) 15 September 1987 and 13 September 1988, (c) 29 September 1987 and 27 September 1988, and (d) 13 October 1987 and 11 October 1988. Longer dashes are for the 1987 positions, whereas shorter dashes are for 1988 positions. 


\section{SEA-ICE CONDITIONS}

\section{Long-term mean ice conditions}

The Chukchi Sea is ice-covered during much of the year and is typically ice-free during July-October. The summer ice edge is generally farthest north during September. The 1973-82 average position of the late summer ice edge, subject to considerable interannual variability, extended from the Siberian coast to the eastern edge of Wrangel Island, then crossed the Chukchi Sea near $72^{\circ} \mathrm{N}$ before veering southward toward the Alaskan coast east of Barrow (Fig. 3). The entire Chukchi Sea has usually become ice-covered by November, whereas the Bering Sea near St. Lawrence Island freezes by mid-December and retains an ice cover until the ice edge retreats north of Bering Strait in June or July (Brower and others, 1988). Mysak and Manak (1989) suggest there is a four to six year cycle of sea-ice extent in the Beaufort and Chukchi seas. These results do not contradict that hypothesis, but are not nearly long enough to test it.

\section{Ice conditions in 1987 and 1988}

The position of the ice edge depends, among other factors, on advection by winds and currents and on air and water temperatures. Whereas our analysis focuses upon wind effects, there are recurrent areas where water temperature plays a major role. The interannual mean minimum ice edge (Fig. 3), and the four 1987 and 1988 cases (Fig. 4), show northward indentations of the ice edge along the Alaskan coast, over the Hope Sea Valley and along Herald Canyon. These indentations are due to the presence, in these regions, of warm water carried northward by the coastal current described above.

The ice-edge locations during late August and midOctober 1987 resembled the 10-year late-summer mean location. The 1988 ice edge was similar to the 1987 edge in late August. However, by mid-September a field of ice had been forced against the Alaskan coast. The ice edge in the vicinity of Herald Canyon remained near $72^{\circ} \mathrm{N}$ until midOctober 1988, as it had in 1987, when an early freeze filled in the western Chukchi with new ice as far south as $70^{\circ} \mathrm{N}$.

The effect of wind on ice-edge position is evident in Figure 4. We use the 1 September map as our "initial condition" and assume (Sverdrup and others, 1942) that the ice moves on the average at $30^{\circ}$ to the right of the wind direction. In 1987, the wind forced the ice first eastward, then westward, with little net northward or southward motion. For example the northern Chukchi winds moved the ice successively toward $80^{\circ} \mathrm{T}, 275^{\circ} \mathrm{T}$, and $290^{\circ} \mathrm{T}$ from its initial (1 September) position. As a result, the ice-edge position was quite stable in 1987 when compared to 1988 . In 1988, strong winds blew the ice southwestward in the last week of August. In late September 1988 the onshore westerly winds drove multi-year pack ice against the beach between Icy Cape and Barrow, closing shipping and trapping three gray whales near Point Barrow.

Ice motion is shown by ARGOS drift-buoy tracks (Fig. 5). In 1987, buoy 7013 was deployed over deep water, whereas 7014 and 7015 were deployed over the Chukchi shelf (Fig. 5). These buoys moved rapidly westward across the northern Chukchi Sea, reaching the longitude of Wrangel Island in four months or less. Buoy 7015 stopped broadcasting in early December, but 7013
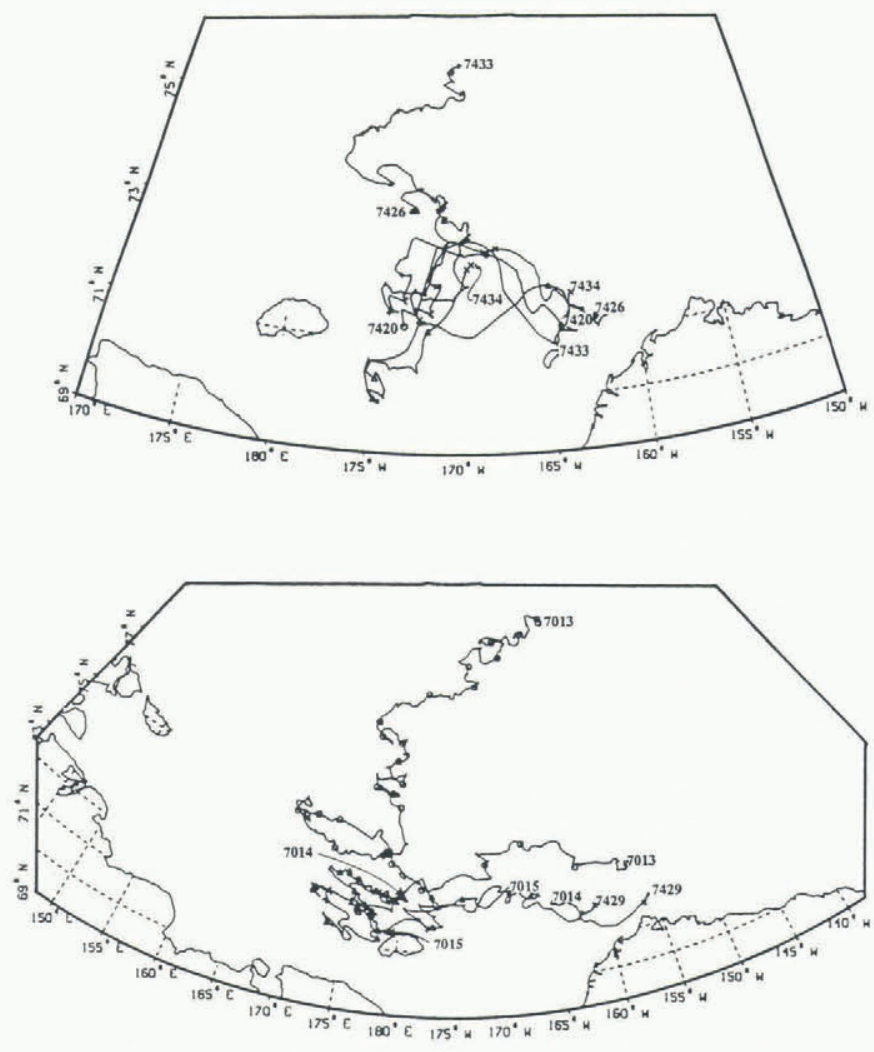

Fig. 5. Trajectories of ice floes equipped with ARGOStracked buoys during 1987 (lower) and 1988 (upper). Buoy numbers indicate deployment sites.

and 7014 continued moving westward and had transmitted another $10-15^{\circ}$ longitude by June 1988 . At that time, 7013 began to move southeastward and then, in October, northward with east-west oscillations. Finally, in May 1989 , it began to move northeastward and continued on this course through December 1989. Buoy 7014's motion was coherent with that of 7013, but its north-south displacements were smaller, and it never moved farther than about a degree north of its latitude of deployment.

In 1988, three additional ARGOS buoys and the meteorological station were deployed over the Chukchi Sea shelf (Fig. 5). As in 1987, the buoys drifted westward, although none of them moved as rapidly or as far west as in the previous year. There were two episodes of northward motion, one in early November 1988 and the other in February 1989. Buoys 7426 and 7433, which continued broadcasting after February 1989, moved slowly northwestward. In May 1989 the only surviving buoy (7433) drifted northeastward. The drifts of all the 1988 buoys were coherent. The motion of 7433 was also coherent with that of $7013,2-3^{\circ}$ farther north, although the north-south excursions of 7433 were greater.

Speed ratios, angle differences and complex correlation coefficients between the buoy-derived ice drifts and the surface-adjusted gradient winds over $30 \mathrm{~d}$ intervals were computed (Fig. 6). These parameters provide a measure of the response of ice motion to local winds. The ratios between scalar mean speed and simple average of the angular difference between the wind and floe- drift directions, and the ratios between the vector mean speeds 


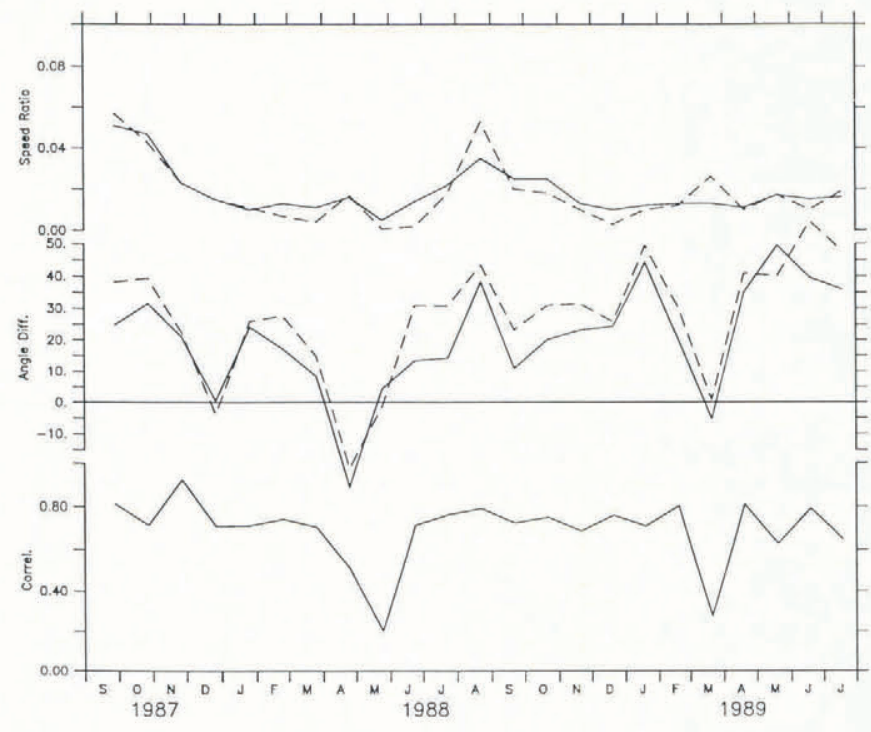

Fig. 6. Computed scalar (solid lines) and vector (dashed lines) ice/wind speed ratio, angle difference and correlation for ARGOS-tracked buoy 7014.

and directions, are plotted. Speed ratios were highest in the less concentrated late summer Chukchi Sea ice, and decreased with ice compaction as winter progressed. Winter ratios were $0.010-0.015$, whereas summer values were typically about 0.025 . Sverdrup and others (1942) give values of 0.014 in late winter and 0.024 in late summer.

Drift angles varied by greater percentages than the speed ratios, and a change with onset of winter and more concentrated ice conditions is not immediately obvious. However, the angles correspond to the drift speeds in Figure 3. For buoy 7014 , angles were generally $20-27^{\circ}$ in January-May 1988, when drift speeds were low, but had increased to $30-38^{\circ}$ by June-August. The $95 \%$ significance for the correlations was generally $\pm 0.25-0.30$, suggesting a reasonably good correlation between floe velocity and the gradient winds. An exception occurred in May 1988, when the correlation coefficient dropped sharply for all the buoys then operating. The reason for this drop in correlation is unknown.

It was noted above that air temperatures were warmer in 1988 than in 1987. At the same time, ice extent was greater in 1988. This suggests that differences in sensible-heat flux between the atmosphere and the ice/ ocean system did not contribute to the extreme shoreward ice extent observed in 1988. This conclusion is contrary to the suggestion by Rogers (1978) that summer ice extent at Barrow correlates inversely with mean air temperatures.

Ice affects the temperature and salinity structure of the underlying water (Paquette and Bourke, 1979; Johnson, 1988). If ice is advected over water whose temperature is above the freezing point of the ice, as in the case of the coastal current described above, the ice melts. In so doing, it cools the water in the surface layer and decreases the salinity. At low temperatures, density is controlled mainly by salinity, so the meltwater forms a surface lens of cold, fresh water at the ice edge. The ice melt-induced stable stratification decouples the surface ice cover from the underlying thermal structure. Hence, ice was present along the Alaskan coast in 1988 at a time when it was underlain at depth by relatively warm water. Presence of warm water at depth cannot be assumed to cause ice melt-back or to delay new ice formation. Only in the absence of a salt-stratified upper layer can heat reach the surface to affect the ice cover.

Ice in the Chukchi Sea formed primarily in situ during autumn freezing in 1987 and 1988. This is obvious in light of the mean westward buoy movements and the simultaneous southward ice-edge advance. The new ice growth was caused by the seasonal change in the radiation balance. However, in 1988, ice advanced more rapidly than in 1987, producing an earlier regional autumn. This early autumn occurred when the wind forced multi-year pack ice into the coastal region where the warm water led to significant melting, in turn preconditioning the upper water column with colder, lower salinity water. Neither unusual water temperatures nor unusual air temperatures contributed to the early autumn freezing in 1988.

The above results are currently being incorporated into a numerical model which will provide more quantitative information on the relative importance of the several factors which influence ice extent in the western Arctic.

\section{SUMMARY AND CONGLUSIONS}

Oceanographic, meteorological and sea-ice data obtained from the northern Bering Sea and Chukchi Sea region during the autumns of 1987,1988 and 1989 were adequate to detect interannual variations from 1987-89 and to determine the pattern of autumn (August-October) ice advance during 1987. The ice edge was significantly farther north in 1987 and 1989 than during 1988, when ice was packed against the coastline from Barrow to Icy Cape. In 1987, in particular, the ice edge was anomalously far north as late as October, and the autumn ice-edge advance was later than in 1988 or 1989.

From mid-August until mid-October 1988 the wind was primarily northerly, averaging nearly $10 \mathrm{~m} \mathrm{~s}^{-1}$ across the Chukchi Sea. Although other years had northerly wind events which were as strong as this, the persistence of the pattern was striking. Embedded in this northerly wind regime was a two-week period at the end of September during which winds were westerly. This blew the ice solidly against the beach along the northwest coast of Alaska, leading to the infamous media event concerning three trapped whales near Barrow. By contrast, other years, such as 1987 and 1989, had higher variances in the wind and fewer instances of northwesterly winds than 1988.

The extreme southward extent of the ice edge from Barrow to Icy Cape during 1988, compared to 1987 and 1989 , was caused by northerly to northwesterly winds which held the summer pack ice against the beach, where accelerated melting led to a highly stratified water column which in turn allowed ice formation to commence earlier than normal. There is no evidence for a sea-water temperature anomaly which would have favored this unusual southward extension of the sea ice, nor is there evidence that the anomaly was related to air temperature. 


\section{ACKNOWLEDGEMENTS}

Primary support for this research has been provided by ONR Contract N00014-82-C-0064 to Science Applications International Corporation (R. Muench) and through contractural support from ONR to the Marine Services Project of NOAA's Pacific Marine Environmental Laboratory (PMEL) (C. Pease and S. Salo). Additional support was provided by the Minerals Management Service, Department of the Interior. This is PMEL Marine Services Project contribution 1202.

\section{REFERENGES}

Aagaard, K., A.T. Roach, and J.D. Schumacher. 1985. On the wind-driven variability of the flow through Bering Strait. 7. Geophys. Res., 90(C4), 7213-7221.

Ahlnäs, K. and G.R. Garrison. 1984. Satellite and oceanographic observations of the warm coastal current in the Chukchi Sea. Artic, 37(3), 244-254.

Brower, W.A., $f r$, R.G. Baldwin, C.N. Williams, $f r$, J.L. Wise, and L.D. Leslie. 1988. Climatic atlas of the outer continental shelf waters and coastal regions of Alaska. Volume III. Chukchi-Beaufort Sea. Anchorage, AK, University of Alaska. Arctic Environmental Information and Data Center.

Coachman, L.K. and K. Aagaard. 1988. Transports through Bering Strait: annual and interannual variability. F. Geophys. Res., 93(C12), 15,535-15,539.

Johnson, W.R. 1989. Current response to wind in the Chukchi Sea: a regional coastal upwelling event. $\mathcal{F}$. Geophys. Res., 94(C2), 2057-2064.

Maykut, G.A. and P.E. Church. 1973. Radiation climate of Barrow, Alaska, 1962-1966. J. Appl. Meteorol., 12(4), $620-628$.
Mysak, L.A. and D.K. Manak. 1989. Arctic sea ice extent and anomalies, 1953-1984. Atmosphere-Ocean, 27(2), 376-405.

Overland, J.E. 1981. Marine climatology of the Bering Sea. In Hood, D.W. and J.A. Calder, eds. The eastern Bering Sea shelf: oceanography and resources. Vol. 1. Seattle, WA, University of Washington Press, 15-22.

Overland, J.E. and C.H. Pease. 1982. Cyclone climatology of the Bering Sea and its relation to sea ice extent. Mon. Weather Rev., 110(1), 5-13.

Paquette, R.G. and R.H. Bourke. 1979. Temperature fine structure near the sea-ice margin of the Chukchi Sea. $\mathcal{F}$. Geophys. Res., 84(C3), 1155-1164.

Paquette, R.G. and R.H. Bourke. 1981. Ocean circulation and fronts as related to ice melt-back in the Chukchi Sea. 7. Geophys. Res., 86(C5), 4215-4230.

Pease, C.H. 1987. Meteorology of the Chukchi Sea: an overview. In Hale, D.A., ed. Chukchi Sea information update. Anchorage, AK, NOAA/NOS Ocean Assessments Division - Alaska Office, 11-19.

Rogers, J.C. 1978. Meteorological factors affecting interannual variability of summertime ice extent in the Beaufort Sea. Mon. Weather Rev., 106(6), 890-897.

Salo, S.A., C.H. Pease, and R.D. Muench. In press. The FREEZE Mesoscale Experiment: 1987 and 1988. NOAA Tech. Memo.

Sverdrup, H.U., M.W. Johnson, and R.H. Fleming. 1942. The oceans: their physics, chemistry, and general biology. Englewood Cliffs, NJ, Prentice-Hall.

Wiseman, W.J., $\mathcal{J r}$, and L.J. Rouse, $\mathcal{F r}$. 1980. A coastal jet in the Chukchi Sea. Arctic, 33(1), 21-29.

The accuracy of references in the text and in this list is the responsibility of the authors, to whom queries should be addressed. 